University of Wollongong

Research Online

Faculty of Engineering - Papers (Archive)

Faculty of Engineering and Information

Sciences

$1-1-2012$

\title{
Effect of gas atmosphere on carbothermal reduction and nitridation of titanium dioxide
}

Sheikh A. Rezan

University of New South Wales

Guangqing Zhang

University of Wollongong, gzhang@uow.edu.au

Oleg Ostrovski

University of New South Wales

Follow this and additional works at: https://ro.uow.edu.au/engpapers

Part of the Engineering Commons

https://ro.uow.edu.au/engpapers/4411

\section{Recommended Citation}

Rezan, Sheikh A.; Zhang, Guangqing; and Ostrovski, Oleg: Effect of gas atmosphere on carbothermal reduction and nitridation of titanium dioxide 2012, 73-81.

https://ro.uow.edu.au/engpapers/4411

Research Online is the open access institutional repository for the University of Wollongong. For further information contact the UOW Library: research-pubs@uow.edu.au 


\title{
Effect of Gas Atmosphere on Carbothermal Reduction and Nitridation of Titanium Dioxide
}

\author{
SHEIKH A. REZAN, GUANGQING ZHANG, and OLEG OSTROVSKI
}

\begin{abstract}
This article examined the reduction/nitridation of rutile in the $\mathrm{He}-\mathrm{N}_{2}, \mathrm{Ar}-\mathrm{N}_{2}$, and $\mathrm{He}(\mathrm{Ar})-\mathrm{H}_{2}-$ $\mathrm{N}_{2}$ gas mixtures, as well as pure nitrogen, in the temperature-programmed and isothermal experiments in a fixed-bed reactor. The extents of reduction and nitridation were determined from the off gas composition and LECO analysis. The off-gas composition was monitored using the infrared sensor $\left(\mathrm{CO}, \mathrm{CO}_{2}\right.$, and $\left.\mathrm{CH}_{4}\right)$ and dew point analyzer $\left(\mathrm{H}_{2} \mathrm{O}\right)$. The phase composition of the reduced samples was analyzed using X-ray diffraction (XRD). The temperature and gas composition had a strong effect on the rutile reduction. The reduction was the fastest in the $\mathrm{H}_{2-}$ $\mathrm{N}_{2}$ gas mixture, followed by a reduction in nitrogen; the rate of reduction/nitridation in the He$\mathrm{N}_{2}$ gas mixture was marginally higher than in the $\mathrm{Ar}-\mathrm{N}_{2}$ gas. The rate of titania reduction/ nitridation in the $\mathrm{He}(\mathrm{Ar})-\mathrm{H}_{2}-\mathrm{N}_{2}$ gas increased with the replacement of $\mathrm{He}(\mathrm{Ar})$ with hydrogen. The article also discusses the mechanisms of reduction/nitridation in different gas atmospheres.
\end{abstract}

DOI: $10.1007 /$ s11663-011-9574-6

(C) The Minerals, Metals \& Materials Society and ASM International 2011

\section{INTRODUCTION}

TITANIUM minerals in the form of natural rutile or ilmenite are processed into titania white pigment and metallic titanium. Ilmenite ore is a major source of titanium; it contains titanium and iron oxides in different proportion (chemical compound ilmenite is $\mathrm{FeTiO}_{3}$ ) and other impurities. Commercial processing of ilmenite ore includes upgrading of the ore to synthetic rutile or titania-rich slag followed by chlorination and reoxidation of titanium tetrachloride to titania in the pigment production or reduction of $\mathrm{TiCl}_{4}$ to titanium metal using magnesium (Kroll process) or sodium (Hunter process). The technologies for titanium metal production under development also use titanium tetrachloride either directly or for the production of titania, which is processed to titanium metal.

The chlorination of $\mathrm{TiO}_{2}$ is implemented in the presence of coke at the temperature of $1073 \mathrm{~K}$ to $1373 \mathrm{~K}\left(800{ }^{\circ} \mathrm{C}\right.$ to $\left.1100{ }^{\circ} \mathrm{C}\right)$ in a fluidized bed. At this temperatures, impurities are also chlorinated what dictates requirements to the raw materials.

Titanium oxycarbide $\mathrm{Ti}(\mathrm{O}, \mathrm{C})$ or oxycarbonitride $\mathrm{Ti}(\mathrm{O}, \mathrm{C}, \mathrm{N})$ can be chlorinated at $473 \mathrm{~K}$ to $673 \mathrm{~K}$ $\left(200{ }^{\circ} \mathrm{C} \text { to } 400{ }^{\circ} \mathrm{C}\right)^{[1,2]}$; chlorination at these temperatures has lower requirements for raw materials quality

SHEIKH A. REZAN, formerly Ph.D. Student, School of Materials Science and Engineering, the University of New South Wales, Sydney, NSW 2052, Australia, is now with the School of Materials \& Mineral Resources Engineering, Universiti Sains Malaysia, 14300 Nibong Tebal, Seberang Perai Selatan, Penang, Malaysia. GUANGQING ZHANG, Lecturer, and OLEG OSTROVSKI, ARC Professorial Fellow, are with the School of Materials Science and Engineering, the University of New South Wales. Contact e-mail: G.Zhang@unsw.edu.au

Manuscript submitted October 21, 2010.

Article published online September 9, 2011. and lower maintenance cost in comparison with the commercial high-temperature processes.

The effect of $\operatorname{Ti}(\mathrm{O}, \mathrm{C})$ or $\mathrm{Ti}(\mathrm{O}, \mathrm{C}, \mathrm{N})$ composition on chlorination is marginal ${ }^{[1,2]}$; however, the chlorination rate of titanium suboxides is significantly slower compared with $\operatorname{Ti}(\mathrm{O}, \mathrm{C})$ or $\operatorname{Ti}(\mathrm{O}, \mathrm{C}, \mathrm{N})$. A study of the synthesis of titanium oxycarbide in References 3 through 5 and oxycarbonitride in this article targeted the subsequent understanding of the effects of operation parameters and mechanisms in the conversion of titania to $\operatorname{Ti}(\mathrm{O}, \mathrm{C})$ or $\operatorname{Ti}(\mathrm{O}, \mathrm{C}, \mathrm{N})$.

Zhang and Ostrovski investigated systematically the synthesis of titanium oxycarbide with a reduction of rutile $^{[6,7]}$ and ilmenite concentrates ${ }^{[8-10]}$ by methanecontaining gas. The optimum conditions for titanium carbide formation included temperature in the range of $1523 \mathrm{~K}$ to $1723 \mathrm{~K}\left(1250{ }^{\circ} \mathrm{C}\right.$ to $\left.1450{ }^{\circ} \mathrm{C}\right)$, methane content of $8 \mathrm{vol}$ pct, and hydrogen content above 35 vol pct. However, reduced iron from ilmenite catalyzes methane decomposition with a deposition of solid carbon, which has a negative effect on the synthesis of titanium carbide.

Dewan et al. ${ }^{[3-5]}$ investigated the synthesis of titanium oxycarbide by carbothermal reduction of titania and ilmenite concentrates in different gas atmospheres. The conversion of titania to titanium carbide was the fastest in hydrogen and can be implemented at lower temperatures compared with a reduction in inert gas.

Compared with titanium oxycarbide, the synthesis of titanium oxycarbonitride is more favorable both thermodynamically and kinetically. The carbothermal synthesis of titanium oxycarbonitride $\mathrm{TiO}_{x} \mathrm{C}_{y} \mathrm{~N}_{z}$ in the $\mathrm{H}_{2}-\mathrm{N}_{2}$ gas atmosphere was discussed previously. ${ }^{[1]} \mathrm{It}$ was demonstrated that the conversion of titania to $\mathrm{TiO}_{x} \mathrm{C}_{y} \mathrm{~N}_{z}$ at $1423 \mathrm{~K}\left(1150{ }^{\circ} \mathrm{C}\right)$ in the $\mathrm{H}_{2}-\mathrm{N}_{2}$ atmosphere followed the sequence: $\mathrm{TiO}_{2} \rightarrow \mathrm{Ti}_{5} \mathrm{O}_{9} \rightarrow \mathrm{Ti}_{4} \mathrm{O}_{7} \rightarrow \mathrm{Ti}_{3} \mathrm{O}_{5} \rightarrow$ $\mathrm{TiO}_{x} \mathrm{C}_{y} \mathrm{~N}_{z}$. The conversion of titania into titanium 
oxycarbonitride at $1423 \mathrm{~K}\left(1150{ }^{\circ} \mathrm{C}\right)$ was completed in 180 minutes; the conversion time decreased to 30 minutes at $1573 \mathrm{~K}\left(1300{ }^{\circ} \mathrm{C}\right)$. Increasing the temperature resulted in the formation of titanium oxycarbonitride with a higher TiC content. Porosity had a minor effect on the reduction/nitridation of titania with the tendency to increase the reduction rate with increasing porosity.

The carbothermal reduction of metal oxides occurs through the gas phase and is affected strongly by the gas atmosphere. This finding was demonstrated by Kononov et $a l^{[12]}$ in the reduction of manganese oxides and ores, and by Dewan et al. ${ }^{[3]}$ in the carbothermal synthesis of titanium carbide and oxycarbide.

Jha and Yoon ${ }^{[13]}$ examined carbothermal reduction/ nitridation of titania in the $\mathrm{N}_{2}-\mathrm{CO}-\mathrm{H}_{2}$ and $\mathrm{Ar}-\mathrm{NH}_{3}-\mathrm{H}_{2}$ gas mixtures of different compositions. However, their data on the effect of gas atmosphere on synthesis of titanium carbonitride are inconclusive. The product of reduction/nitridation reaction in Reference 13 included $\mathrm{Ti}_{3} \mathrm{O}_{5}$ and TiCN phases. The TiCN phase was not observed in Reference 11; titania in the $\mathrm{H}_{2}-\mathrm{N}_{2}$ gas atmosphere was reduced to titanium oxycarbonitride.

The aim of this article is to study the effect of gas atmosphere on the carbothermal reduction/nitridation of titania. Reduction/nitridation experiments were conducted in the $\mathrm{He}-\mathrm{N}_{2}, \mathrm{Ar}-\mathrm{N}_{2}, \mathrm{He}-\mathrm{H}_{2}-\mathrm{N}_{2}$, and $\mathrm{Ar}-\mathrm{H}_{2}-\mathrm{N}_{2}$ gas mixtures and pure nitrogen. The difference between the carbothermal reduction of titania in the $\mathrm{He}-\mathrm{N}_{2}$ and Ar- $\mathrm{N}_{2}$ gas atmospheres is in the mass transfer in the gas phase; diffusion coefficients of gas species in $\mathrm{He}$ are significantly higher than in Ar. For example, the diffusion coefficient of $\mathrm{CO}$ in $\mathrm{He}$ is approximately four times of that in Ar. Diffusion coefficients of gaseous species in $\mathrm{He}$ and $\mathrm{H}_{2}$ gases are approximately the same. However, hydrogen is a reactive gas. A comparison of the reduction behavior in the $\mathrm{He}-\mathrm{N}_{2}$ and $\mathrm{H}_{2}-\mathrm{N}_{2}$ gas atmospheres will shed a light on the role of hydrogen in carbothermal synthesis of titanium oxycarbonitride.

\section{EXPERIMENTAL}

A titanium dioxide-graphite mixture was prepared by wet mixing with the addition of $0.3 \mathrm{wt}$ pet carboxymethylcellulose. The carbon-to-titanium molar ratio was 4.5 , with 50 pct excess carbon relative to the amount needed for the reduction of titania to titanium carbide. The powder mixture was pressed at $20 \mathrm{kN}$ for 2 minutes into pellets with a diameter of $8 \mathrm{~mm}$ and a thickness of $\sim 11 \mathrm{~mm}$. The mass of a pellet was $\sim 1.0 \mathrm{~g}$. The sample porosity was 34.8 pct. The experimental setup and procedure were presented in the previous papers. ${ }^{[3,11]}$

The carbothermal reduction/nitridation was carried out in the mixtures of nitrogen with argon, helium, or hydrogen, or in pure nitrogen. A gas mixture was formed by mixing the individual gases. The flow rate of gases was controlled by Brooks mass flow controllers (model 5850E; Brooks Instruments, Hatfield, PA). An infrared $\mathrm{CO} / \mathrm{CO}_{2} / \mathrm{CH}_{4}$ sensor (Advanced Optima Uras 14; ABB, Ladenburgh, Germany) was used to monitor concentrations of $\mathrm{CO}, \mathrm{CO}_{2}$, and $\mathrm{CH}_{4}$ in the effluent gas.
A dew point monitor to measure water vapor content in the off-gas was installed in the gas outlet line between the reaction vessel and the $\mathrm{CO} / \mathrm{CH}_{4} / \mathrm{CO}_{2}$ analyzer.

In the temperature-programmed reduction experiments, the furnace temperature was ramped from $623 \mathrm{~K}$ to $1873 \mathrm{~K}\left(350{ }^{\circ} \mathrm{C}\right.$ to $\left.1600{ }^{\circ} \mathrm{C}\right)$ at a heating rate of $2 \mathrm{~K} \mathrm{~min}^{-1}$. The gas composition was monitored continuously in the course of the sample heating/ reduction. The sample temperature in isothermal experiments reached the assigned value in 13 to 15 minutes.

The phase composition of samples taken in the progress of reduction was analyzed by powder X-ray diffraction (Siemens D5000; Siemens Aktiengesellschaft, Germany, and Philips X'pert Multipurpose X-Ray Diffraction System; PANalytical B.V., Almelo, the Netherlands). The oxygen, nitrogen, and carbon contents of the reduced samples were measured using LECO analyzers. For carbon, the LECO CS-224 Carbon/Sulfur analyzer (LECO Corporation, St Joseph, MI) was used. In this analysis, carbon in a sample was oxidized in oxygen at $1473 \mathrm{~K}\left(1200{ }^{\circ} \mathrm{C}\right)$ to $\mathrm{CO}_{2}$, which was measured by an infrared detector. A $0.1-$ to $0.2-\mathrm{g}$ sample was placed in an alumina crucible with a catalyst to accelerate the reaction. The oxygen and nitrogen contents were determined by the LECO TC-436DR Oxygen/Nitrogen analyzer. A sample inside a tin capsule was placed into a nickel basket, which was loaded into a graphite crucible. By heating the sample to a high temperature, all oxygen present in a sample reacted with the carbon of graphite crucible forming $\mathrm{CO}$ and $\mathrm{CO}_{2}$, whereas nitrogen was converted to $\mathrm{N}_{2}$ gas. The $\mathrm{CO}$ and $\mathrm{CO}_{2}$ produced were detected by infrared sensors. The $\mathrm{N}_{2}$ content was measured by thermal conductivity sensors after the removal of $\mathrm{CO}$ and $\mathrm{CO}_{2}$.

The extent of reduction was calculated from the offgas composition and the composition of reduced samples by LECO analysis. When titanium suboxides were undetectable by X-ray diffraction (XRD) in the reduced samples, the composition of titanium oxycarbonitride was calculated using oxygen, nitrogen, and carbon concentrations from the LECO analysis.

The extent of reduction $(X)$ of rutile was defined as the fraction of oxygen removed in the process of reduction of titania into $\operatorname{Ti}(\mathrm{O}, \mathrm{C}, \mathrm{N})$. The extent of nitridation $X_{\mathrm{N}}$ was defined as the fraction of titanium that was present as nitride (TiN) in the reduced sample $\left(X_{\mathrm{N}}=100\right.$ pct when TiN is the only phase in the reduced sample). Similarly, the extent of carburization $X_{\mathrm{C}}$ was defined as the fraction of titanium that was present as carbide ( $\mathrm{TiC}$ ) in the reduced sample $\left(X_{\mathrm{C}}=100\right.$ pet when titania is totally converted to $\mathrm{TiC})$. For the phase $\mathrm{Ti}(\mathrm{O}, \mathrm{C}, \mathrm{N})$, the molar fractions of titanium monoxide, carbide, and nitride are defined with the notation $\mathrm{TiO}_{x} \mathrm{C}_{y} \mathrm{~N}_{z}$.

The errors in measurement of oxygen, nitrogen, and carbon contents by LECO analyses were 2 to $3 \mathrm{wt}$ pct. The relative errors of calculated extents of reduction and nitridation were dependent on the contents of oxygen, nitrogen, and carbon in the reduced samples. In general, the errors of calculated extents of reduction and nitridation were below 1 pct and 3 pct, correspondingly. 


\section{RESULTS}

\section{A. Temperature-Programmed Reduction}

The temperature programmed reduction (TPR) experiments were conducted in pure nitrogen, and in the He- $\mathrm{N}_{2}\left(50 \mathrm{vol}\right.$ pet $\left.\mathrm{N}_{2}\right)$ and $\operatorname{Ar}-\mathrm{N}_{2}\left(50 \mathrm{vol}\right.$ pct $\left.\mathrm{N}_{2}\right)$ gas mixtures with the gas flow rate $1.5 \mathrm{~L} \mathrm{~min}^{-1}$.

The $\mathrm{CO}$ evolution curves in the course of rutile reduction in different gas atmospheres are presented in Figure 1. This figure also includes the $\mathrm{CO}$ evolution curve obtained in rutile reduction in a 50 vol pct $\mathrm{H}_{2}-$ 50 vol pet $\mathrm{N}_{2}$ gas mixture. ${ }^{[1]}$ Table I shows the LECO data and phase composition of the reduced samples after completion of the TPR experiments. The highest $\mathrm{CO}$ evolution rate and highest final extent of reduction and nitridation were obtained for a sample reduced in the $\mathrm{H}_{2}-\mathrm{N}_{2}$ gas mixture. The peak of $\mathrm{CO}$ evolution (maximum reduction rate) corresponded to approximately $1473 \mathrm{~K}\left(1200{ }^{\circ} \mathrm{C}\right)$. The rate of reduction in nitrogen was slower than in the $\mathrm{H}_{2}-\mathrm{N}_{2}$ gas mixture; in this case, the maximum reduction rate was observed at approximately $1573 \mathrm{~K}\left(1300{ }^{\circ} \mathrm{C}\right)$. However, the nitrogen content in titanium oxycarbonitride was approximately the same as in the sample reduced in the $\mathrm{H}_{2}-\mathrm{N}_{2}$ gas mixture. The reduction curves obtained in the $\mathrm{He}-\mathrm{N}_{2}$ and $\mathrm{Ar}-\mathrm{N}_{2}$ gas mixtures were close to each other; the final extent of reduction achieved in the $\mathrm{He}-\mathrm{N}_{2}$ gas mixture was 1.3 pct higher than in the $A r-N_{2}$ gas mixture. A reduction in the $\mathrm{He}-\mathrm{N}_{2}$ and $\mathrm{Ar}-\mathrm{N}_{2}$ gases was slower than in $\mathrm{N}_{2}$ and $\mathrm{H}_{2}-\mathrm{N}_{2}$.

The XRD patterns of the samples reduced in different gas atmospheres were similar. All the samples contained titanium oxycarbonitride and residual carbon. The

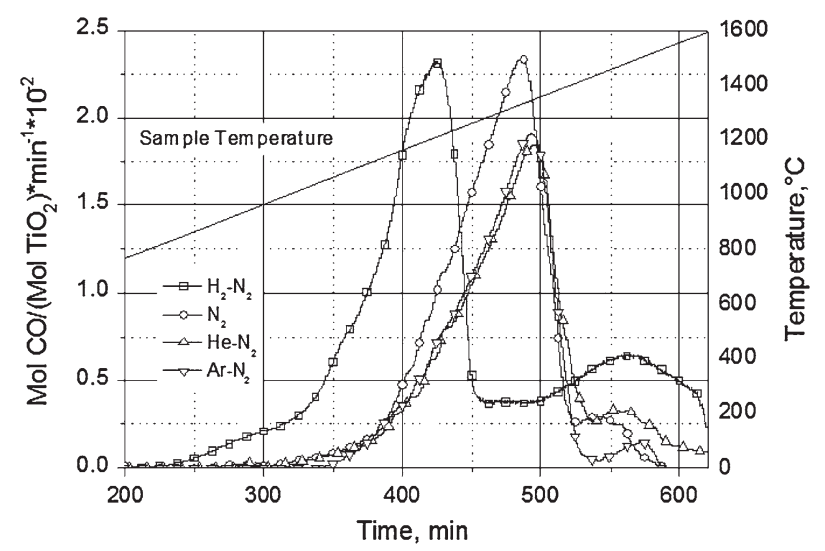

Fig. 1- $\mathrm{CO}$ evolution rate in the temperature-programmed reduction of titania in various gas atmospheres. A gas mixture contained $50 \mathrm{vol}$ pet $\mathrm{N}_{2}$ and $50 \mathrm{vol}$ pet of another gas. major difference was the height of the carbon peaks, which was the lowest for the sample reduced in the $\mathrm{H}_{2}$ $\mathrm{N}_{2}$ gas mixture. This is attributed to partial loss of carbon because of gasification reaction with hydrogen to form methane. ${ }^{[3]}$ As shown in Table I, total carbon content in this sample, measured by LECO, was $15.3 \mathrm{wt}$ pct, whereas it was above $30 \mathrm{wt}$ pct in the samples reduced in the gas without hydrogen.

\section{B. Isothermal Reduction}

\section{Reduction of titania in nitrogen}

Reduction curves obtained in nitrogen at $1473 \mathrm{~K}$ to $1773 \mathrm{~K}\left(1200{ }^{\circ} \mathrm{C}\right.$ to $\left.1500{ }^{\circ} \mathrm{C}\right)$ are presented in Figure 2. The XRD patterns of samples after 180 minutes of reduction at different temperatures are shown in Figure 3. After 180 minutes of reduction at $1473 \mathrm{~K}$ $\left(1200{ }^{\circ} \mathrm{C}\right)$, a sample was reduced only to 45.8 pct. The reduced sample contained titanium oxycarbonitride, $\mathrm{Ti}_{3} \mathrm{O}_{5}$, and a small amount of $\mathrm{TiO}_{2}$. The extent and rate of reduction increased with increasing temperature. The effect of temperature was particularly strong when temperature increased from $1473 \mathrm{~K}$ to $1523 \mathrm{~K}\left(1200{ }^{\circ} \mathrm{C}\right.$ to $1250{ }^{\circ} \mathrm{C}$ ). The extent of reduction jumped to $78.5 \mathrm{pct}$ as a result of conversion of $\mathrm{Ti}_{3} \mathrm{O}_{5}$ into titanium oxycarbonitride. Traces of rutile were observed in the XRD spectra of samples reduced at $1473 \mathrm{~K}$ to $1573 \mathrm{~K}$ $\left(1200{ }^{\circ} \mathrm{C}\right.$ to $\left.1300{ }^{\circ} \mathrm{C}\right)$; titania became undetectable in the samples reduced at higher temperatures. $\mathrm{Ti}_{3} \mathrm{O}_{5}$ was present in the samples reduced at $1473 \mathrm{~K}$ to $1673 \mathrm{~K}$ $\left(1200{ }^{\circ} \mathrm{C}\right.$ to $1400{ }^{\circ} \mathrm{C}$ ). Titania was converted to titanium oxycarbonitride totally at $1723 \mathrm{~K}$ to $1773 \mathrm{~K}\left(1450{ }^{\circ} \mathrm{C}\right.$ to $1500{ }^{\circ} \mathrm{C}$ ). The reduction in $\mathrm{N}_{2}$ was much slower than in the $\mathrm{H}_{2}-\mathrm{N}_{2}$ gas mixture, ${ }^{[11]}$ in which titanium suboxides became undetectable after 180 minutes at $1423 \mathrm{~K}$ $\left(1150{ }^{\circ} \mathrm{C}\right)$, and $89.6 \mathrm{pct}$ of the reduction was reached. The shape of the reduction curve in $\mathrm{N}_{2}$ at $1723 \mathrm{~K}$ $\left(1450{ }^{\circ} \mathrm{C}\right)$ was similar to that in the $\mathrm{H}_{2}-\mathrm{N}_{2}$ gas mixture at $1523 \mathrm{~K}\left(1250{ }^{\circ} \mathrm{C}\right)$; however, the final extent of reduction in $\mathrm{N}_{2}$ at $1723 \mathrm{~K}\left(1450{ }^{\circ} \mathrm{C}\right)$ was close to the extent of reduction in the $\mathrm{H}_{2}-\mathrm{N}_{2}$ gas mixture at $1423 \mathrm{~K}\left(1150{ }^{\circ} \mathrm{C}\right)$, which was close to 90 pct. After reduction at $1773 \mathrm{~K}$ $\left(1500{ }^{\circ} \mathrm{C}\right)$ for 180 minutes, the extents of reduction and nitridation reached 93.7 pct and 78.1 pct, respectively.

\section{Reduction of titania in the $\mathrm{He}-\mathrm{N}_{2}$ and $\mathrm{Ar}-\mathrm{N}_{2}$} gas mixtures

The reduction curves obtained in the $50 \mathrm{vol}$ pct He-50 vol pet $\mathrm{N}_{2}$ gas mixture at $1473 \mathrm{~K}$ to $1773 \mathrm{~K}$ $\left(1200{ }^{\circ} \mathrm{C}\right.$ to $\left.1500{ }^{\circ} \mathrm{C}\right)$ are shown in Figure 4. Figure 5 presents the XRD patterns of the reduced samples for 180 minutes. A LECO analysis of the reduced samples

Table I. Chemical and Phase Compositions of Samples Reduced in the TPR Experiments

\begin{tabular}{lcccccc}
\hline Gas & $\begin{array}{c}\text { Oxygen } \\
\text { (wt pct) }\end{array}$ & $\begin{array}{c}\text { Nitrogen } \\
\text { (wt pct) }\end{array}$ & $\begin{array}{c}\text { Carbon } \\
\text { (wt pct) }\end{array}$ & $\begin{array}{c}X \\
\text { (pct) }\end{array}$ & $\begin{array}{c}X_{\mathrm{N}} \\
\text { (pct) }\end{array}$ & \multicolumn{1}{c}{ Phases } \\
\hline 50 vol pct $\mathrm{H}_{2}-50$ vol pet $\mathrm{N}_{2}$ & 0.4 & 14.9 & 15.3 & 99.3 & 71.2 & $\mathrm{TiO}_{0.01} \mathrm{C}_{0.27} \mathrm{~N}_{0.71}+\mathrm{C}$ \\
100 vol pct $\mathrm{N}_{2}$ & 0.7 & 11.8 & 31.9 & 98.3 & 70.9 & $\mathrm{TiO}_{0.03} \mathrm{C}_{0.26} \mathrm{~N}_{0.71}+\mathrm{C}$ \\
50 vol pct $\mathrm{He}-50$ vol pct $\mathrm{N}_{2}$ & 1.3 & 11.1 & 32.2 & 96.6 & 66.2 & $\mathrm{TiO}_{0.07} \mathrm{C}_{0.27} \mathrm{~N}_{0.66}+\mathrm{C}$ \\
50 vol pet Ar-50 vol pet $\mathrm{N}_{2}$ & 1.8 & 10.5 & 32.8 & 95.3 & 61.8 & $\mathrm{TiO}_{0.09} \mathrm{C}_{0.29} \mathrm{~N}_{0.62}+\mathrm{C}$ \\
\hline
\end{tabular}




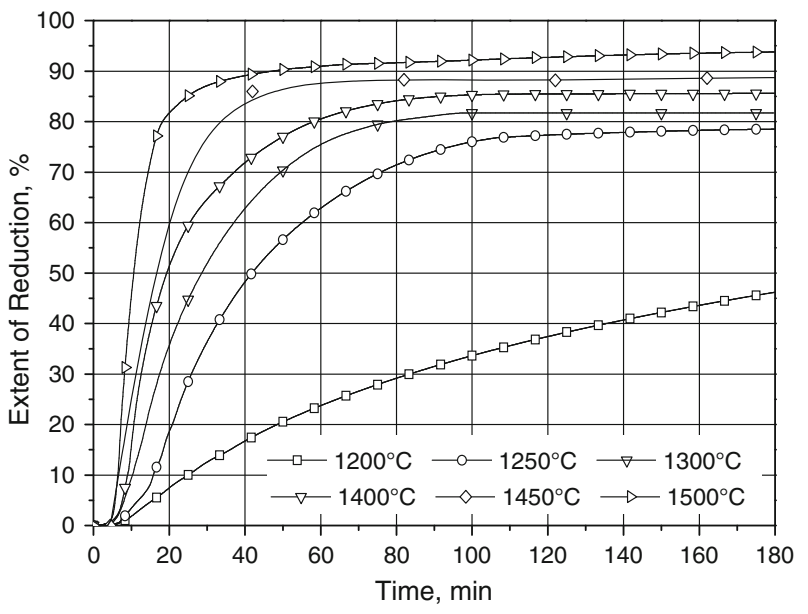

Fig. 2-Extent of reduction of titania in nitrogen at $1473 \mathrm{~K}$ to $1773 \mathrm{~K}\left(1200{ }^{\circ} \mathrm{C}\right.$ to $\left.1500{ }^{\circ} \mathrm{C}\right)$.

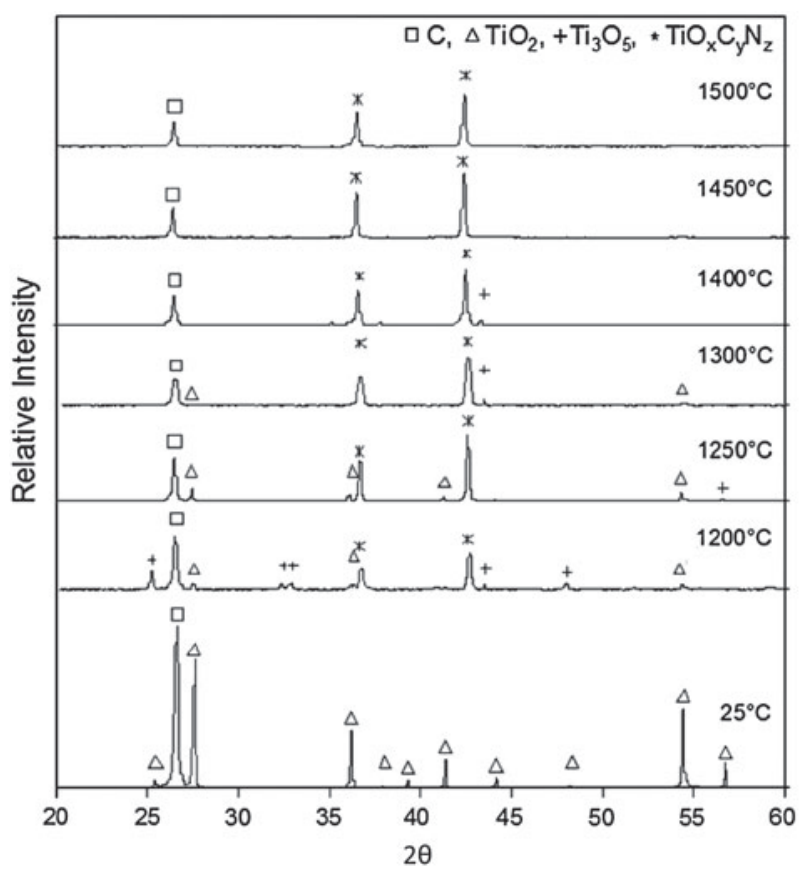

Fig. 3-XRD patterns of samples reduced in $\mathrm{N}_{2}$ at different temperatures for $180 \mathrm{~min}$.

and their composition are given in Table II. The rate and extent of reduction were lower than the values obtained in the $\mathrm{H}_{2}-\mathrm{N}_{2}$ gas mixture ${ }^{[1]}$ and in pure $\mathrm{N}_{2}$ (Figure 2). The sample reduced at $1473 \mathrm{~K}\left(1200^{\circ} \mathrm{C}\right)$ for 180 minutes had an extent of reduction 38.5 pct; the XRD pattern shows that rutile was reduced mostly to $\mathrm{Ti}_{3} \mathrm{O}_{5}$ with formation of a small amount of titanium oxycarbonitride. Increasing the temperature from $1473 \mathrm{~K}$ to $1523 \mathrm{~K}$ $\left(1200{ }^{\circ} \mathrm{C}\right.$ to $\left.1250{ }^{\circ} \mathrm{C}\right)$ increased the rate of reduction significantly, which boosted the extent of reduction to 76.2 pct. Traces of titania were observed in the XRD spectrum of a sample reduced at $1673 \mathrm{~K}\left(1400{ }^{\circ} \mathrm{C}\right)$, although $\mathrm{Ti}_{3} \mathrm{O}_{5}$ was not detected in the XRD pattern of the sample reduced at $1523 \mathrm{~K}\left(1250{ }^{\circ} \mathrm{C}\right)$. Titania was

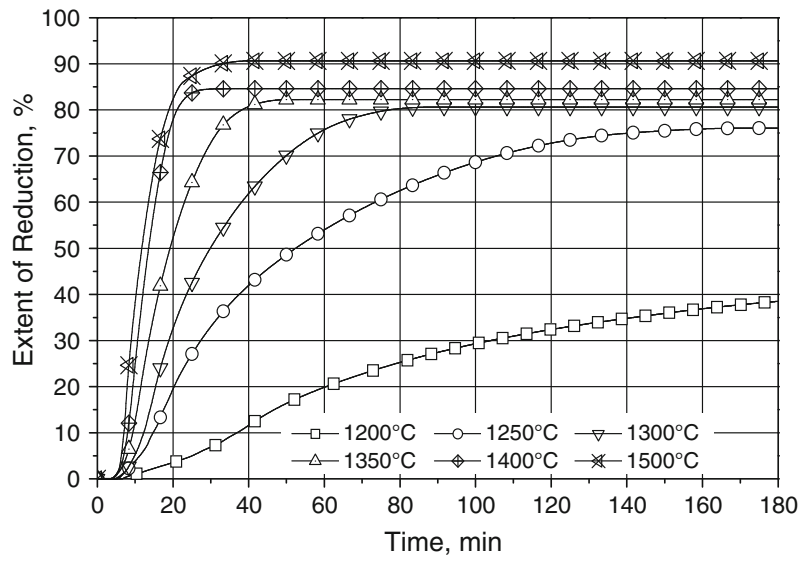

Fig. 4-Extent of reduction of titania in the 50 vol pet He-50 vol pet $\mathrm{N}_{2}$ gas mixture at $1473 \mathrm{~K}$ to $1773 \mathrm{~K}\left(1200{ }^{\circ} \mathrm{C}\right.$ to $\left.1500{ }^{\circ} \mathrm{C}\right)$.

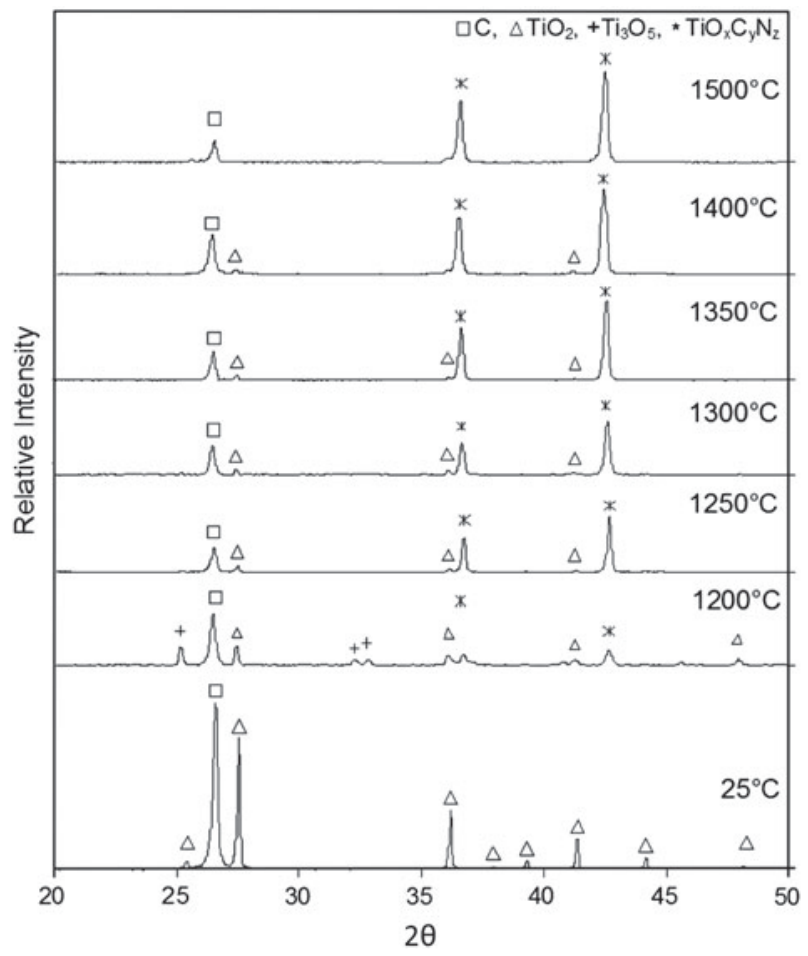

Fig. 5-XRD patterns of the samples reduced in the 50 vol pct He$50 \mathrm{vol}$ pct $\mathrm{N}_{2}$ gas mixture at different temperatures for $180 \mathrm{~min}$.

totally converted to titanium oxycarbonitride only at $1773 \mathrm{~K}\left(1500^{\circ} \mathrm{C}\right)$, when the extent of reduction increased to 90.7 pct and the extent of nitridation reached 78.4 pct. The reduction curves obtained in the reduction of titania in the Ar- $\mathrm{N}_{2}$ gas mixture were similar to those obtained in the $\mathrm{He}-\mathrm{N}_{2}$ gas, although the rate of reduction in the Ar- $\mathrm{N}_{2}$ gas mixture was slightly lower.

The phase development in the course of reduction of titania in the 50 vol pct $\mathrm{He}-50$ vol pct $\mathrm{N}_{2}$ gas mixture was studied at $1573 \mathrm{~K}\left(1300{ }^{\circ} \mathrm{C}\right)$. The XRD patterns of the samples taken in the course of reduction are presented in Figure 6. After 10 minutes of reduction, the detected phases included suboxides $\mathrm{Ti}_{4} \mathrm{O}_{7}$ and $\mathrm{Ti}_{3} \mathrm{O}_{5}$ in addition 
to unreduced titania and residual carbon. Titanium oxycarbonitride was detected after 20 minutes of reduction, when the major oxide became $\mathrm{Ti}_{3} \mathrm{O}_{5}$, whereas $\mathrm{Ti}_{4} \mathrm{O}_{7}$ became undetectable. Subsequent reduction involved the conversion of $\mathrm{Ti}_{3} \mathrm{O}_{5}$ to titanium oxycarbonitride. The $\mathrm{Ti}_{3} \mathrm{O}_{5}$ phase did not disappear until 120 minutes of reduction. The $\mathrm{TiO}_{2}$ peaks in the samples reduced from 10 to 180 minutes were small; however, no obvious change in their height in the progress of reduction was observed. A careful inspection showed that the residual titania was present only in a thin surface layer of the sample pellet, which was related to the trace amount of oxygen and moisture in the inlet gas.

The phase development in the progress of titania reduction in the 50 vol pct $\mathrm{Ar}-50$ vol pct $\mathrm{N}_{2}$ gas mixture was studied also at $1573 \mathrm{~K}\left(1300^{\circ} \mathrm{C}\right)$. The phase development in the Ar- $\mathrm{N}_{2}$ gas mixture was similar to that in the $\mathrm{He}-\mathrm{N}_{2}$ gas mixture.

3. Effect of $\mathrm{H}_{2}$ and $\mathrm{N}_{2}$ contents in the gas phase on the reduction of titania

Reduction experiments were conducted at $1473 \mathrm{~K}$ $\left(1200{ }^{\circ} \mathrm{C}\right)$ in the $\mathrm{H}_{2}-\mathrm{N}_{2}-\mathrm{He}$ gas mixture of different composition. In these experiments, either the $\mathrm{H}_{2}$ content in the gas mixture was varied at constant 50 vol pct $\mathrm{N}_{2}$ content or the $\mathrm{N}_{2}$ content was varied at constant $50 \mathrm{vol}$ pct $\mathrm{H}_{2}$ content.

In reduction experiments, methane was detected in effluent gas; the concentration in experiments with 50 vol pet $\mathrm{H}_{2}-50$ vol pet $\mathrm{N}_{2}$ reached $100 \mathrm{ppm}$ at $1473 \mathrm{~K}$ $\left(1200{ }^{\circ} \mathrm{C}\right)$ and decreased with increasing temperature.

The reduction curves with varied $\mathrm{H}_{2}$ concentration are given in Figure 7. The LECO analysis and phase composition determined by the XRD analysis of reduced samples are presented in Table III. The $\mathrm{H}_{2}$ content had a strong effect on the rate and extent of reduction and nitridation. As shown in Figure 7, the carbothermal reduction in the 50 vol pet $\mathrm{He}-50$ vol pet $\mathrm{N}_{2}$ gas mixture was slow; the final extent of reduction and nitridation after 180 minutes was less than 40 pct and 20 pct, respectively. The reduction products included $\mathrm{Ti}_{3} \mathrm{O}_{5}$ and a small amount of titanium oxycarbonitride. Titania conversion was not complete in this case. The addition of 5 vol pct $\mathrm{H}_{2}$ increased the extent of reduction significantly to 74.4 pct and the extent of nitridation to 55.7 pct. Some amount of $\mathrm{Ti}_{3} \mathrm{O}_{5}$ was detected in the reduced sample as the only titanium oxide. The extents of reduction and nitridation increased to $86.1 \mathrm{pct}$ and 71.0 pct, respectively, with an addition of $10 \mathrm{vol}$ pct of $\mathrm{H}_{2}$ to the gas mixture, and titanium suboxides were not detected in the reduced sample. Subsequent increasing $\mathrm{H}_{2}$ content to 30 and 50 vol pct shortened the reduction period to 100 minutes and 70 minutes, respectively. The final extent of reduction was not affected significantly by the $\mathrm{H}_{2}$ content in the range of 10 to 50 vol pct; the effect of hydrogen on the extent of nitridation was more remarkable, it increased to 85.7 pct with $50 \mathrm{vol}$ pct addition of $\mathrm{H}_{2}$ in the gas atmosphere.

Figure 8 presents the reduction curves obtained in experiments with varied $\mathrm{N}_{2}$ content. A LECO analysis and phase composition determined by the XRD analysis of reduced samples are presented in Table IV.In the gas mixture of $50 \mathrm{vol}$ pet $\mathrm{H}_{2}-50$ vol pct $\mathrm{He}$ without $\mathrm{N}_{2}$ addition, a reduction of 75 pct was achieved. It increased to 90.2 pet when 5 vol pet $\mathrm{N}_{2}$ was added to

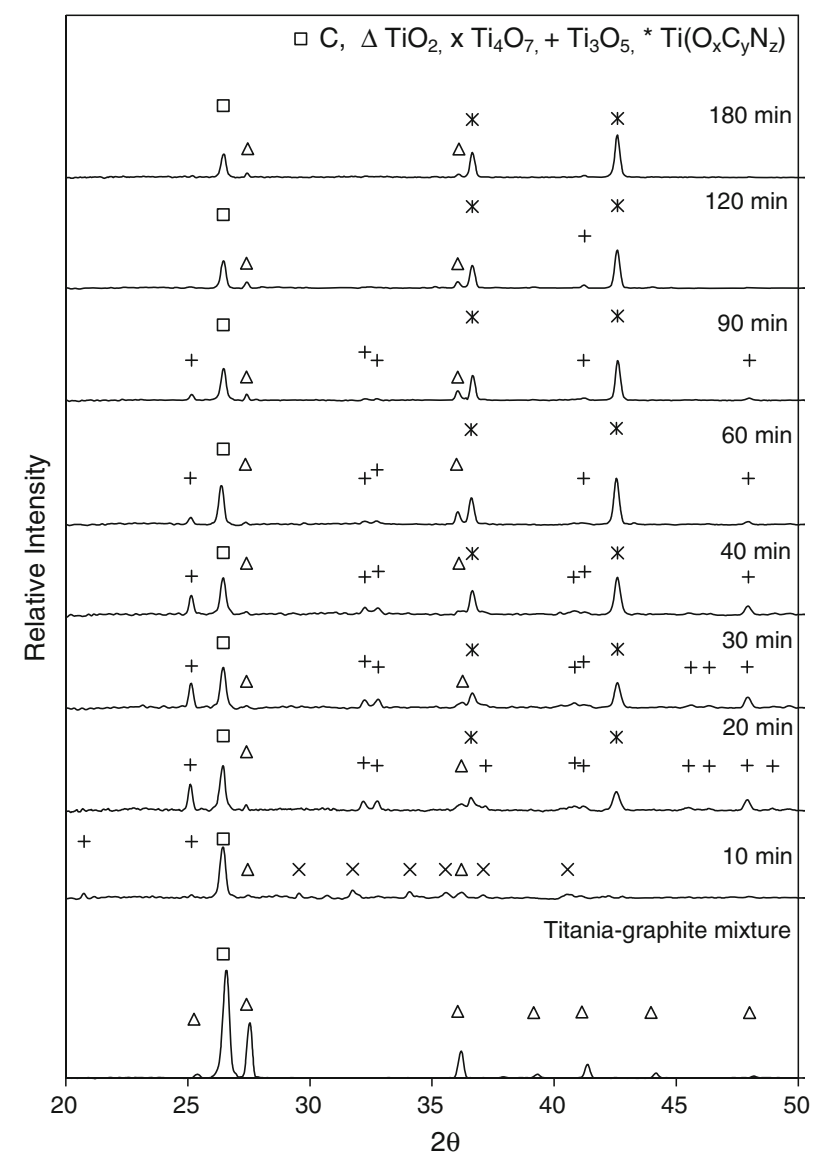

Fig. 6-XRD patterns of samples in progress of reduction in the 50 vol pet $\mathrm{He}-50$ vol pet $\mathrm{N}_{2}$ gas mixture at $1573 \mathrm{~K}\left(1300{ }^{\circ} \mathrm{C}\right)$.

Table II. Chemical and Phase Compositions of Samples Reduced in the 50 Vol Pct He-50 Vol Pct $\mathrm{N}_{2}$ Gas Mixture for 180 Min

\begin{tabular}{lcccccl}
\hline Time (min) & $\begin{array}{c}\text { Oxygen } \\
\text { (wt pct) }\end{array}$ & $\begin{array}{c}\text { Nitrogen } \\
\text { (wt pct) }\end{array}$ & $\begin{array}{c}\text { Carbon } \\
\text { (wt pct) }\end{array}$ & $\begin{array}{c}X \\
\text { (pct) }\end{array}$ & $\begin{array}{c}X_{\mathrm{N}} \\
(\text { pct) }\end{array}$ & \multicolumn{1}{c}{ Phases } \\
\hline 1200 & 16.9 & 2.3 & 38.2 & 38.5 & 19.1 & $\mathrm{TiO}_{2}+\mathrm{Ti}_{3} \mathrm{O}_{5}+\mathrm{TiO}_{x} \mathrm{C}_{y} \mathrm{~N}_{z}+\mathrm{C}$ \\
1250 & 7.9 & 8.9 & 33.4 & 76.2 & 61.6 & $\mathrm{TiO}_{2}+\mathrm{TiO}_{x} \mathrm{C}_{y} \mathrm{~N}_{z}+\mathrm{C}$ \\
1300 & 6.6 & 10.4 & 32.2 & 80.2 & 71.5 & $\mathrm{TiO}_{2}+\mathrm{TiO}_{x} \mathrm{C}_{y}+\mathrm{C}_{z}$ \\
1350 & 6.3 & 11.5 & 31.9 & 82.4 & 74.4 & $\mathrm{TiO}_{2}+\mathrm{TiO}_{x} \mathrm{C}_{y}+\mathrm{C}_{z}$ \\
1400 & 5.6 & 12.4 & 26.0 & 84.7 & 78.3 & $\mathrm{TiO}_{2}+\mathrm{TiO}_{x} \mathrm{C}_{y} \mathrm{~N}_{z}+\mathrm{C}$ \\
1500 & 3.6 & 13.0 & 24.8 & 90.7 & 78.4 & $\mathrm{TiO}_{0.19} \mathrm{C}_{0.03} \mathrm{~N}_{0.78}+\mathrm{C}$ \\
\hline
\end{tabular}




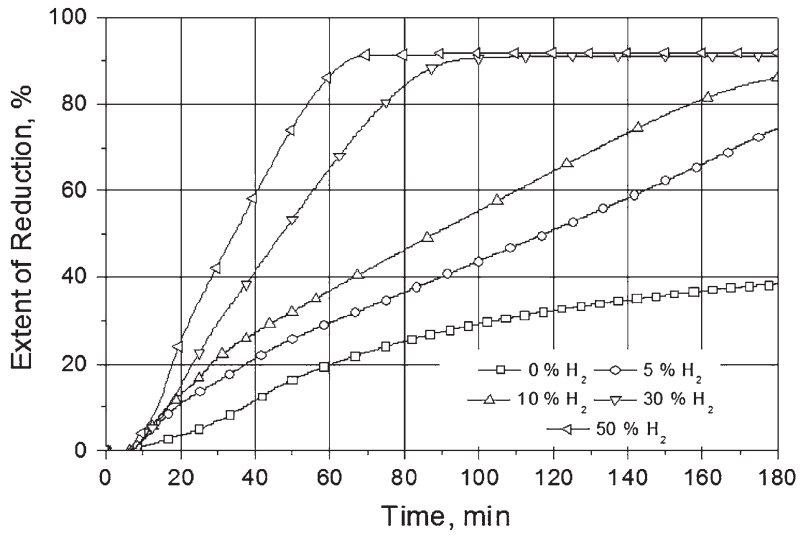

Fig. 7-Extent of the reduction of titania in the $\mathrm{H}_{2}-\mathrm{N}_{2}-\mathrm{He}$ gas mixtures $\left(50\right.$ vol pet $\mathrm{N}_{2}$ ) with varied $\mathrm{H}_{2}$ concentration at $1473 \mathrm{~K}\left(1200^{\circ} \mathrm{C}\right)$.

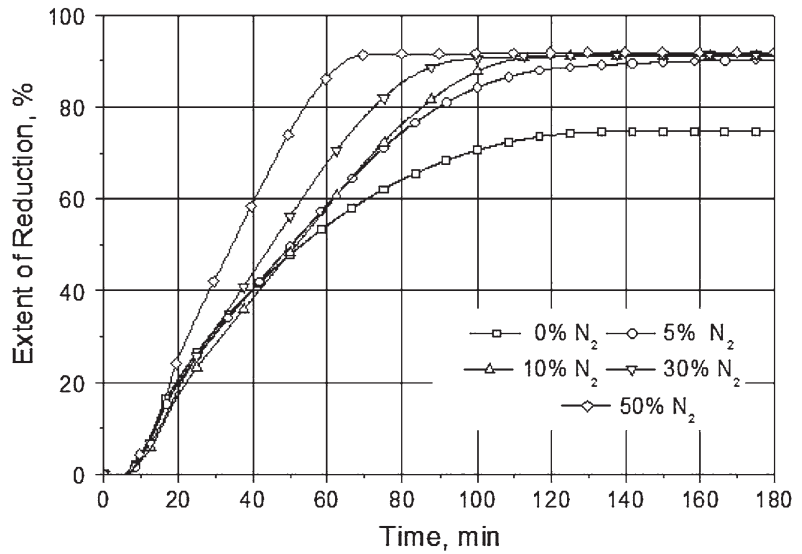

Fig. 8-Extent of the reduction of titania in the $\mathrm{H}_{2}-\mathrm{N}_{2}-\mathrm{He}$ gas mixtures $\left(50\right.$ vol pet $\left.\mathrm{H}_{2}\right)$ with varied $\mathrm{N}_{2}$ concentration at $1473 \mathrm{~K}\left(1200^{\circ} \mathrm{C}\right)$.

Table III. Chemical and Phase Compositions of Samples Reduced in the $\mathrm{H}_{2}-\mathrm{N}_{2}-\mathrm{He}$ Gas Mixtures (50 vol pet $\left.\mathrm{N}_{2}\right)$ with Different $\mathrm{H}_{2}$ Concentration at $1473 \mathrm{~K}\left(1200{ }^{\circ} \mathrm{C}\right)$ for $180 \mathrm{Min}$

\begin{tabular}{|c|c|c|c|c|c|c|}
\hline $\begin{array}{l}\mathrm{H}_{2} \text { Content } \\
\text { (vol pct) }\end{array}$ & $\begin{array}{l}\text { Oxygen } \\
\text { (wt pct) }\end{array}$ & $\begin{array}{l}\text { Nitrogen } \\
\text { (wt pct) }\end{array}$ & $\begin{array}{l}\text { Carbon } \\
\text { (wt pct) }\end{array}$ & $\begin{array}{c}X \\
(\mathrm{pct})\end{array}$ & $\begin{array}{c}X_{\mathrm{N}} \\
(\mathrm{pct})\end{array}$ & Phases \\
\hline 0 & 16.9 & 2.3 & 38.2 & 38.5 & 19.1 & $\mathrm{TiO}_{2}+\mathrm{Ti}_{3} \mathrm{O}_{5}+\mathrm{TiO}_{x} \mathrm{C}_{y} \mathrm{~N}_{z}+\mathrm{C}$ \\
\hline 10 & 4.8 & 10.8 & 31.7 & 86.1 & 71.0 & $\mathrm{TiO}_{0.28} \mathrm{C}_{0.001} \mathrm{~N}_{0.71}+\mathrm{C}$ \\
\hline 30 & 3.2 & 12.9 & 29.6 & 91.0 & 81.5 & $\mathrm{TiO}_{0.17} \mathrm{C}_{0.01} \mathrm{~N}_{0.82}+\mathrm{C}$ \\
\hline 50 & 2.6 & 13.6 & 28.4 & 92.9 & 85.7 & $\mathrm{TiO}_{0.13} \mathrm{C}_{0.01} \mathrm{~N}_{0.86}+\mathrm{C}$ \\
\hline
\end{tabular}

the gas mixture. Increasing $\mathrm{N}_{2}$ content in the reducing gas did not significantly increase the extent of reduction. With 50 vol pct $\mathrm{N}_{2}$ addition, the extent of reduction was 92.9 pct. However, the rate of reduction increased remarkably and the reduction time shortened corresponding to the increase in the $\mathrm{N}_{2}$ content in the gas mixture. Without $\mathrm{N}_{2}$ addition, titanium oxycarbide was formed in carbothermal reduction of titania, and a small amount of $\mathrm{Ti}_{2} \mathrm{O}_{3}$ was detected in the reduced sample. The addition of $5 \mathrm{vol}$ pct $\mathrm{N}_{2}$ resulted in the formation of titanium oxycarbonitride, and 59 pct of the titanium was nitridated. No titanium suboxide was detected by XRD. The extent of nitridation increased further to $67.8,80.4$, and 85.7 pct, correspondingly with 10, 30, and $50 \mathrm{vol}$ pet $\mathrm{N}_{2}$ in the reduction atmosphere.

\section{DISCUSSION}

A reaction sequence in reduction/nitridation of titania in the $\mathrm{H}_{2}-\mathrm{N}_{2}$ gas mixture was discussed previously. ${ }^{[11]}$ The phases detected by the XRD analysis in the progress of reduction/nitridation in the $\mathrm{H}_{2}-\mathrm{N}_{2}$ gas mixture at $1423 \mathrm{~K}$ $\left(1150{ }^{\circ} \mathrm{C}\right)$ were developed in the following sequence:

$$
\mathrm{TiO}_{2} \rightarrow \mathrm{Ti}_{5} \mathrm{O}_{9} \rightarrow \mathrm{Ti}_{4} \mathrm{O}_{7} \rightarrow \mathrm{Ti}_{3} \mathrm{O}_{5} \rightarrow \mathrm{TiO}_{x} \mathrm{C}_{y} \mathrm{~N}_{z}
$$

A similar reduction/nitridation sequence was observed in experiments in the $\mathrm{He}-\mathrm{N}_{2}$ gas mixture at $1573 \mathrm{~K}$ $\left(1300^{\circ} \mathrm{C}\right)$, although the conversion of titania to titanium oxycarbonitride was not completed.
An analysis of the reduction curves and phase development in the progress of reduction shows that the conversion of titania to $\mathrm{Ti}_{3} \mathrm{O}_{5}$ was fast; the subsequent conversion of $\mathrm{Ti}_{3} \mathrm{O}_{5}$ to titanium oxycarbonitride was relatively slow and can be considered as the rate controlling stage of the carbothermal reduction of titania. The reduction of $\mathrm{Ti}_{3} \mathrm{O}_{5}$ to titanium oxycarbonitride, which is a solid solution of titanium oxide, carbide, and nitride, can be presented by the following equation:

$$
\begin{aligned}
\mathrm{Ti}_{3} \mathrm{O}_{5}+(5-3 x+3 y) \mathrm{C}+(3 / 2) z \mathrm{~N}_{2} \\
=3(x[\mathrm{TiO}]+y[\mathrm{TiC}]+z[\mathrm{TiN}])+(5-3 x) \mathrm{CO} \\
\Delta G_{2}=x \Delta G_{\mathrm{TiO}}^{\circ}+y \Delta G_{\mathrm{TiC}}^{\circ}+z \Delta G_{\mathrm{TiN}}^{\circ} \\
+3 \mathrm{R} T \ln \frac{\left(a_{\mathrm{TiO}}\right)^{x}\left(a_{\mathrm{TiC}}\right)^{y}\left(a_{\mathrm{TiN}}\right)^{z} P_{\mathrm{CO}}^{5 / 3-x}}{P_{\mathrm{N}_{2}}^{z / 2}} \\
=x(599.0-0.3255 T)+y(1279.1-0.7948 T) \\
+z(836.4-0.5601 T) \\
+3 \mathrm{R} T \ln \frac{\left(a_{\mathrm{TiO}}\right)^{x}\left(a_{\mathrm{TiC}}\right)^{y}\left(a_{\mathrm{TiN}}\right)^{z} P_{\mathrm{CO}}^{5 / 3-x}}{P_{\mathrm{N}_{2}}^{z / 2}}
\end{aligned}
$$

where $a_{\mathrm{i}}$ represents the activity of $\mathrm{TiO}, \mathrm{TiC}$, and TiN in titanium oxycarbonitride; $\Delta G_{\mathrm{TiO}}^{\circ}$ and $\Delta G_{\mathrm{TiC}}^{\circ}$ are the standard Gibbs free energy change for formation of $\mathrm{TiO}$ and $\mathrm{TiC}$ by the reaction of $\mathrm{Ti}_{3} \mathrm{O}_{5}$ with graphite; and $\Delta G_{\mathrm{TiN}}^{\circ}$ is the standard Gibbs free energy change for the 
Table IV. Chemical and Phase Compositions of Samples Reduced in the $\mathrm{H}_{2}-\mathrm{N}_{2}-\mathrm{He}$ Gas Mixtures (50 vol pet $\left.\mathrm{H}_{2}\right)$ with Different $\mathrm{N}_{2}$ Concentration at $1473 \mathrm{~K}\left(1200^{\circ} \mathrm{C}\right)$ for $180 \mathrm{Min}$

\begin{tabular}{lccccrc}
\hline $\begin{array}{l}\mathrm{N}_{2} \text { Content } \\
\text { (vol pct) }\end{array}$ & $\begin{array}{c}\text { Oxygen } \\
\text { (wt pct) }\end{array}$ & $\begin{array}{c}\text { Nitrogen } \\
\text { (wt pct) }\end{array}$ & $\begin{array}{c}\text { Carbon } \\
\text { (wt pct) }\end{array}$ & $\begin{array}{c}X \\
\text { (pct) }\end{array}$ & $\begin{array}{c}X_{\mathrm{N}} \\
\text { (pct) }\end{array}$ & Phases \\
\hline 0 & 7.7 & 0.0 & 36.4 & 75.0 & 0.0 & $\mathrm{Ti}_{2} \mathrm{O}_{3}+\mathrm{TiO}_{x} \mathrm{C}_{y} \mathrm{~N}_{z}+\mathrm{C}$ \\
5 & 3.6 & 9.6 & 32.6 & 90.2 & 59.2 & $\mathrm{TiO}_{0.20} \mathrm{C}_{0.21} \mathrm{~N}_{0.59}+\mathrm{C}$ \\
10 & 3.3 & 10.7 & 31.6 & 91.0 & 67.8 & $\mathrm{TiO}_{0.18} \mathrm{C}_{0.14} \mathrm{~N}_{0.68}+\mathrm{C}$ \\
30 & 3.2 & 12.8 & 29.7 & 91.3 & 80.4 & $\mathrm{TiO}_{0.17} \mathrm{C}_{0.03} \mathrm{~N}_{0.80}+\mathrm{C}_{2}$ \\
50 & 2.6 & 13.6 & 30.2 & 92.9 & 85.7 & $\mathrm{TiO}_{0.14} \mathrm{C}_{0.001} \mathrm{~N}_{0.86}+\mathrm{C}$ \\
\hline
\end{tabular}

formation of $\mathrm{TiN}$ by a reaction of $\mathrm{Ti}_{3} \mathrm{O}_{5}$ with graphite and $\mathrm{N}_{2}$. The Gibbs free energy change for reaction [2] and other reactions considered in this article was calculated using data from NIST-JANAF Thermochemical Tables in the temperature range of $1300 \mathrm{~K}$ to $1800 \mathrm{~K}\left(1027^{\circ} \mathrm{C}\right.$ to $\left.1527^{\circ} \mathrm{C}\right) .^{[14]}$

Carbothermal reduction starts with solid-solid reaction at the contact points of the graphite-titania particles. Subsequent reduction proceeds through the gas phase. Carbon is transferred from graphite to oxide in the form of $\mathrm{CO}$ when titania is reduced in the $\mathrm{N}_{2}, \mathrm{~N}_{2-}$ $\mathrm{He}$, or $\mathrm{N}_{2}$-Ar gas mixtures, or as $\mathrm{CH}_{4}$ when $\mathrm{H}_{2}$ is present in the gas phase.

The conversion of $\mathrm{Ti}_{3} \mathrm{O}_{5}$ to $\mathrm{TiO}_{x} \mathrm{C}_{y} \mathrm{~N}_{z}$ by $\mathrm{CO}$ can be presented by the following reaction:

$$
\begin{aligned}
& \mathrm{Ti}_{3} \mathrm{O}_{5}+(5-3 x+6 y) \mathrm{CO}+(1.5 z) \mathrm{N}_{2} \\
&=3(x[\mathrm{TiO}]+y[\mathrm{TiC}]+z[\mathrm{TiN}])+(5-3 x+3 y) \mathrm{CO}_{2} \\
& \Delta G_{3}= x \Delta G_{\mathrm{TiO}}^{*}+y \Delta G_{\mathrm{TiC}}^{*}+z \Delta G_{\mathrm{TiN}}^{*} \\
&+3 \mathrm{R} T \ln \frac{\left(a_{\mathrm{TiO}}\right)^{x}\left(a_{\mathrm{TiC}}\right)^{y}\left(a_{\mathrm{TiN}}\right)^{z} P_{\mathrm{CO}_{2}}^{5 / 3-x+y}}{P_{\mathrm{CO}}^{5 / 3-x+2 y} P_{\mathrm{N}_{2}}^{z / 2}} \\
&= x(269.2+0.0157 T)+y(-40.2+0.5699 T) \\
&+z(11.8+0.2928 T) \\
&+3 \mathrm{R} T \ln \frac{\left(a_{\mathrm{TiO}}\right)^{x}\left(a_{\mathrm{TiC}}\right)^{y}\left(a_{\mathrm{TiN}}\right)^{z} P_{\mathrm{CO}_{2}}^{5 / 3-x+y}}{P_{\mathrm{CO}}^{5 / 3-x+2 y} P_{\mathrm{N}_{2}}^{z / 2}}
\end{aligned}
$$

where $\Delta G_{\mathrm{TiO}}^{*}$ and $\Delta G_{\mathrm{TiC}}^{*}$ are the standard Gibbs free energy change for formation of $\mathrm{TiO}$ and $\mathrm{TiC}$ by reaction of $\mathrm{Ti}_{3} \mathrm{O}_{5}$ with $\mathrm{CO} ; \Delta G_{\mathrm{TiN}}^{*}$ is the Gibbs free energy change for formation of $\mathrm{TiN}$ by reaction of $\mathrm{Ti}_{3} \mathrm{O}_{5}$ with $\mathrm{CO}$ and $\mathrm{N}_{2} \cdot \mathrm{CO}_{2}$ formed in reaction [3] is converted to $\mathrm{CO}$ by the Boudouard reaction [4]:

$$
\begin{gathered}
\mathrm{CO}_{2}+\mathrm{C}=2 \mathrm{CO} \\
\Delta G_{4}^{\circ}=-21.1+0.190 T \quad[\mathrm{~kJ}]
\end{gathered}
$$

When $\mathrm{H}_{2}$ is present in the gas phase, it reacts with carbon to form methane, which reduces $\mathrm{Ti}_{3} \mathrm{O}_{5}$ to titanium oxycarbonitride:

$$
\begin{gathered}
\mathrm{C}+2 \mathrm{H}_{2}=\mathrm{CH}_{4} \\
\Delta G_{5}^{\circ}=-92.5+0.112 T \quad[\mathrm{~kJ}]
\end{gathered}
$$

$$
\begin{aligned}
& \mathrm{Ti}_{3} \mathrm{O}_{5}+(5-3 x+3 y) \mathrm{CH}_{4}+(1.5 z) \mathrm{N}_{2} \\
& =3(x[\mathrm{TiO}]+y[\mathrm{TiC}]+z[\mathrm{TiN}])+(5-3 x) \mathrm{CO} \\
& \quad+2(5-3 x+3 y) \mathrm{H}_{2}
\end{aligned}
$$

$$
\begin{aligned}
\Delta G_{6}= & x \Delta G_{\mathrm{TiO}}^{\#}+y \Delta G_{\mathrm{TiC}}^{\#}+z \Delta G_{\mathrm{TiN}}^{\#} \\
& +3 \mathrm{R} T \ln \frac{\left(a_{\mathrm{TiO}}\right)^{x}\left(a_{\mathrm{TiC}}\right)^{y}\left(a_{\mathrm{TiN}}\right)^{z} P_{\mathrm{CO}}^{5 / 3-x} P_{\mathrm{H}_{2}}^{2(5 / 3-x+y)}}{P_{\mathrm{CH}_{4}}^{5 / 3-x+y} P_{\mathrm{N}_{2} z / 2}} \\
= & x(784.0-0.549 T)+y(2019.1-1.69 T) \\
& +z(1298.9-1.12 T) \\
& +3 \mathrm{R} T \ln \frac{\left(a_{\mathrm{TiO}}\right)^{x}\left(a_{\mathrm{TiC}}\right)^{y}\left(a_{\mathrm{TiN}}\right)^{z} P_{\mathrm{CO}}^{5 / 3-x} P_{\mathrm{H}_{2}}^{2(5 / 3-x+y)}}{P_{\mathrm{CH}_{4}}^{5 / 3-x+y} P_{\mathrm{N}_{2}}^{z / 2}}
\end{aligned}
$$

where $\Delta G_{\mathrm{TiO}}^{\#}$ and $\Delta G_{\mathrm{TiC}}^{\#}$ are the standard Gibbs free energy change for formation of $\mathrm{TiO}$ and $\mathrm{TiC}$ by reaction of $\mathrm{Ti}_{3} \mathrm{O}_{5}$ with $\mathrm{CH}_{4} ; \Delta G_{\mathrm{TiN}}^{\#}$ is the Gibbs free energy change for formation of $\mathrm{TiN}$ by reaction of $\mathrm{Ti}_{3} \mathrm{O}_{5}$ with $\mathrm{CH}_{4}$ and $\mathrm{N}_{2}$. Intermediate $\mathrm{CO}$ or $\mathrm{CH}_{4}$ in the carbothermal reduction does not change the thermodynamics of the overall reaction [2].

Figure 9 presents the calculated equilibrium partial pressures of $\mathrm{CO}_{2}$ for reactions [3] and [4] and that of $\mathrm{CH}_{4}$ for reaction [5], assuming that titanium oxycarbonitride is an ideal solution containing $15 \mathrm{~mol} \mathrm{pct} \mathrm{TiO}$, $10 \mathrm{~mol}$ pet TiC, and $75 \mathrm{~mol}$ pet $\mathrm{TiN}\left(\mathrm{TiO}_{0.15} \mathrm{C}_{0.10} \mathrm{~N}_{0.75}\right)$; the partial pressures of $\mathrm{H}_{2}, \mathrm{~N}_{2}$, and $\mathrm{CO}$ in the gas phase were assumed at $50 \mathrm{kPa}, 50 \mathrm{kPa}$, and $1 \mathrm{kPa}$, respectively. The equilibrium partial pressure of $\mathrm{CO}_{2}$ for reduction Reaction [3] is low, close to $10^{-4} \mathrm{kPa}$. The equilibrium partial pressure of $\mathrm{CO}_{2}$ for the Boudouard reaction [4] is equal to $1.42 \times 10^{-7} \mathrm{kPa}$ at $1423 \mathrm{~K}$ $\left(1150{ }^{\circ} \mathrm{C}\right)$ and $3.7 \times 10^{-8} \mathrm{kPa}$ at $1573 \mathrm{~K}\left(1300{ }^{\circ} \mathrm{C}\right)$. The equilibrium partial pressure of $\mathrm{CH}_{4}$ is 2 to 3 orders higher than that of $\mathrm{CO}_{2}$ for reaction [3].

Rankin and Wynnyckyj ${ }^{[15]}$ demonstrated that the rate of carbothermal reduction reactions can be controlled by the intrinsic gas phase diffusion of the intermediate $\mathrm{CO}_{2}$ between the oxide and graphite particle when the $\mathrm{CO}_{2}$ partial pressure is low. The diffusion control in the gas phase for solid-solid reactions is expected when a partial pressure of intermediate gaseous species is below $10^{-2} \mathrm{kPa} .^{[15]}$ This is the case of intermediate $\mathrm{CO}_{2}$, for which the equilibrium partial pressure with $\mathrm{Ti}_{3} \mathrm{O}_{5}$ and $\mathrm{TiO}_{0.15} \mathrm{C}_{0.10} \mathrm{~N}_{0.75}$ is near $10^{-4} \mathrm{kPa}$ in the temperature range examined in this article. However, for carbothermal reduction/nitridation in the $\mathrm{H}_{2}$-containing gases, the 


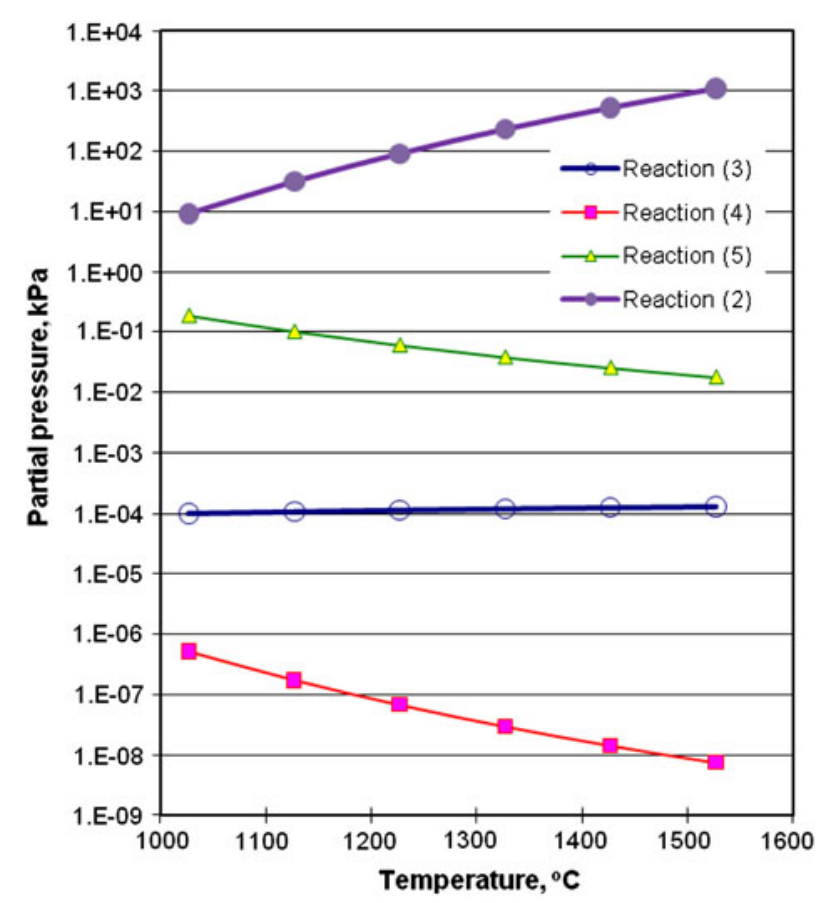

Fig. 9-Equilibrium partial pressure of $\mathrm{CO}_{2}$ for reactions [3] and [4], $\mathrm{CH}_{4}$ for reaction [5], and $\mathrm{CO}$ for reaction [2] calculated for an ideal $\mathrm{TiO}_{0.15} \mathrm{C}_{0.10} \mathrm{~N}_{0.75}$ solution. Partial pressures of $\mathrm{H}_{2}, \mathrm{CO}$, and $\mathrm{N}_{2}$ are assumed at $50 \mathrm{kPa}$ (reaction [5]), $1 \mathrm{kPa}$ and $50 \mathrm{kPa}$ (reactions [3] and [4]), respectively.

partial pressure of intermediate $\mathrm{CH}_{4}$ is well above $10^{-2} \mathrm{kPa}$. Therefore, under the experimental conditions described in this work, the carbothermal reduction in pure nitrogen or its mixtures with an inert gas was controlled by the diffusion of $\mathrm{CO}_{2}$ from oxide particles to graphite, and a reduction in a hydrogen-nitrogen mixture was controlled by the intrinsic kinetics of a reduction reaction (reduction of $\mathrm{Ti}_{3} \mathrm{O}_{5}$ by $\mathrm{CH}_{4}$ ).

A change in $\mathrm{N}_{2}$ concentration in the $\mathrm{He}-\mathrm{H}_{2}-\mathrm{N}_{2}$ gas mixture (constant $\mathrm{H}_{2}$ content at $50 \mathrm{vol}$ pct) had a strong effect on $X, X_{\mathrm{N}}$, and the reduction rate (Figure 8 and Table IV). A significant difference in the reduction behavior of titania in the $\mathrm{H}_{2}-\mathrm{He}$ gas mixture $(0$ vol pct $\mathrm{N}_{2}$ ) and $\mathrm{H}_{2}-\mathrm{He}-\mathrm{N}_{2}$ gas mixture with only 5 vol pct $\mathrm{N}_{2}$ is a manifestation of the fact that the conversion of titania to oxycarbonitride is more favorable thermodynamically and kinetically than that to oxycarbide. TiN is a more stable titanium compound compared with $\mathrm{TiC}$ and $\mathrm{TiO}$. The equilibrium temperature for $\mathrm{TiN}$ formation by carbothermal reduction of $\mathrm{Ti}_{3} \mathrm{O}_{5}$ under standard conditions is $1493 \mathrm{~K} \quad\left(1220{ }^{\circ} \mathrm{C}\right)$, which is $116 \mathrm{~K}$ and $347 \mathrm{~K}$ lower than those of $\mathrm{TiC}$ and $\mathrm{TiO}$, respectively. The nitrogen partial pressure in reduction experiments was much higher than the partial pressure of $\mathrm{CH}_{4}$ or $\mathrm{CO}$, which are reaction intermediates in formation of $\mathrm{TiC}$. These thermodynamic and kinetic parameters are favorable for the TiN formation and explain the high TiN fraction in titanium oxycarbonitride.

\section{CONCLUSIONS}

The gas composition had a strong effect on the carbothermal reduction/nitridation of titania to titanium oxycarbonitride. The reduction was the fastest in the $\mathrm{H}_{2}-\mathrm{N}_{2}$ gas mixture, and it was slower in pure nitrogen and the slowest in the $\mathrm{Ar}-\mathrm{N}_{2}$ gas.

Increasing temperature resulted in formation of titanium oxycarbonitride with higher TiC content.

The carbothermal reduction of solid oxides proceeds through the gas phase. In the reduction in inert atmosphere, titanium oxide was reduced by $\mathrm{CO}$ with the formation of $\mathrm{CO}_{2}$, which was converted to $\mathrm{CO}$ by the Boudouard reaction. The equilibrium partial pressure of $\mathrm{CO}_{2}$ produced in the reduction reaction is low, close to $10^{-4} \mathrm{kPa}$. At such a low $\mathrm{CO}_{2}$ partial pressure, carbothermal reduction reactions can be controlled by the intrinsic diffusion of the intermediate $\mathrm{CO}_{2}$ between the oxide and graphite particles.

Hydrogen was involved in the carbothermal reduction reactions. After reduction in hydrogen-containing gas, titanium oxides were reduced by methane, which was formed by the reaction of hydrogen with carbon. The equilibrium partial pressure of $\mathrm{CH}_{4}$ was 2 to 3 orders higher than that of $\mathrm{CO}_{2}$. This finding explains why the carbothermal reduction was faster in hydrogen than in argon and helium. Partial replacement of $\mathrm{N}_{2}$ by $\mathrm{H}_{2}$ also increased the diffusivity of gas species in the gas phase, however, with an insignificant effect on the reaction kinetics.

The addition of hydrogen to the gas atmosphere in the process of carbothermal synthesis of titanium oxycarbonitride has a positive effect on the reaction kinetics; it reduces the reaction temperature and time.

\section{ACKNOWLEDGMENTS}

This research was supported under the Australian Research Council's Discovery Projects funding scheme (project number DP0771059). Professor Ostrovski is the recipient of an Australian Research Council Professorial Fellowship. Sheikh Abdul Rezan was the recipient of a scholarship from the Universiti Sains Malaysia.

\section{REFERENCES}

1. A. Adipuri, G. Zhang, and O. Ostrovski: Metall. Mater. Trans. B, 2008, vol. 39B, pp. 23-34.

2. A. Adipuri, G. Zhang, and O. Ostrovski: Ind. Eng. Chem. Res., 2009, vol. 48, pp. 779-87.

3. M. Dewan, G. Zhang, and O. Ostrovski: Metall. Mater. Trans. B, 2009, vol. 40B, pp. 62-69.

4. M. Dewan, G. Zhang, and O. Ostrovski: ISIJ Int., 2010, vol. 50, pp. 647-53.

5. M.A.R. Dewan, G. Zhang, and O. Ostrovski: Metall. Mater. Trans. B, 2010, vol. 41B, pp. 182-92.

6. G. Zhang and O. Ostrovski: Intern. J. Min. Process., 2002, vol. 64, pp. 201-18.

7. G. Zhang and O. Ostrovski: Can. Metall. Q., 2001, vol. 40, pp. 489-98. 
8. G. Zhang and O. Ostrovski: Can. Metall. Q., 2001, vol. 40, pp. 317-26

9. G. Zhang and O. Ostrovski: Metall. Mater. Trans. B, 2001 , vol. 32B, pp. 465-73.

10. G. Zhang and O. Ostrovski: Metall. Mater. Trans. B, 2000 , vol. 31B, pp. 129-39.

11. S.A. Rezan, G. Zhang, and O. Ostrovski: J. Am. Ceram. Soc. 2011, DOI:10.1111/j.1551-2916.2011.04703.x.
12. R. Kononov, O. Ostrovski, and S. Ganguly: Metall. Mater. Trans. $B, 2008$, vol. 39 , pp. 662-68.

13. A. Jha and S.J. Yoon: J. Mater. Sci., 1999, vol. 34, pp. $307-$ 22

14. M.W. Chase: NIST-JANAF Thermochemical Tables, 4th ed. American Chemistry Society, Washington, DC, 1998.

15. W.J. Rankin and J.R. Wynnyckyj: Metall. Mater. Trans. B, 1997, vol. 28B, pp. 307-19 